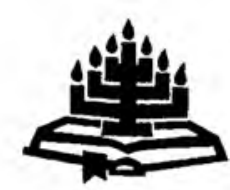

\title{
Die nuwe hemel en die nuwe aarde: dogmatiese en etiese oorwegings oor 'n aspek van die eskatologie
}

\author{
J.H. van Wyk \\ Skool vir Kerkwetenskappe \\ Potchefstroomse Universiteit vir $\mathrm{CHO}$ \\ POTCHEFSTROOM
}

\begin{abstract}
A new heaven and a new earth: dogmatic and ethical considerations of an aspect of eschatology

Most Christians confess their belief in a new heaven and a new earth. The question, however, arises as to what exactly is meant by and expected from the acceptance of the concept of a new heaven and a new earth. In some Christian traditions the idea of heaven is predominantly emphasized-thus neglecting the notion of earth. In line with this emphasis the general idea of "after death we go to heaven" is stimulated. In other views, the new earth as final destination plays an important role, while the concept of the new heaven is underrated. In this article it is attempted not only to investigate different theological views concerning the new heaven and the new earth, but also to present a Biblical perspective on this topic of discussion.
\end{abstract}

\section{Vraagstelling}

Ek sien 'n nuwe hemel kom,

'n aarde nuut en vry.

Die see en al wat skei, verdwyn.

God self kom by ons bly.

Só het die digter I.L. de Villiers die grootse eskatologiese uitspraak van Openbaring 21:1 in ' $n$ himne weergegee. Die vraag is egter of Christene die inhoud van hierdie pragtige lied verstaan wanneer dit in 'n erediens aangehef word. Wat word met "nuwe hemel" bedoel? Die woonplek van God - soos Grudem (1994:1160) oordeel? Maar dis tog ondenkbaar, want watter vernuwing sou die woonplek van God nodig hê? Verder, is die nuwe hemel die ewige bestemming van die uitverkorenes - soos waarskynlik die meeste Christene 
oordeel (Grenz, 1994:840), en ook die standpunt van ou gereformeerde teoloè soos Waldaeus was (Honig, 1938:847-848) - of is dit die nuwe aarde? Wat word bedoel met nuwe aarde: 'n totaal ander aarde of hierdie aarde hernuwe?

Dit is onder andere hierdie vrae wat in die artikel aan die orde gestel sal word, want dat daaroor dikwels wyd-uiteenlopende menings bestaan, kan nie betwyfel word nie. Wanneer verskillende eskatologiese ontwerpe ${ }^{1}$ nagegaan word, blyk al gou dat binne sommige sienings die hemel - as uiteindelike bestemming - 'n oorheersende plek inneem, terwyl in ander die (nuwe) hemel 'n onbelangrike plek inneem of totaal verdwyn. By sommige teoloe is die Groot Toekoms volledig hemels en bo-aards (idealisme), by ander is die Toekoms weer volledig aards en onhemels (realisme). 'n Derde groep probeer 'n sintese tussen hierdie twee standpunte bewerk.

By 'n idealistiese benadering verdwyn die nuwe aarde in die eskatologiese verwagting en word slegs of hoofsaaklik in terme van die (nuwe) hemel gedink. So oordeel Boice (1986:715-718; vgl. Grudem, 1994:619) dat die mens se ewige bestemming in die hemel is; oor die nuwe aarde word geen woord gerep nie (vir die standpunt van Calvyn, vgl. Van Wyk, 1984:41-43). Blykbaar dink die vertalers van Die lewende Bybel (1982) ook in hierdie rigting, aangesien daar by sowel Matteus 22:23-33 as Lukas 20:27-40 dié opskrif verskyn: "Is daar 'n huwelik in die hemel?" Die "toekomstige wêreld" (NAV), of "daardie eeu" (OAV), waarvan Christus in Lukas melding maak, word deur die vertalers van Die lewende Bybel klaarblyklik met die "hemel" geidentifiseer. Die vraag kan egter gestel word of daar dan nie aanduidings in die Skrif self is dat die eindbestemming in die hemel sal wees nie (2 Kor. 5:1-5; Heb. $11: 16$; 1 Pet. 1:4)? So ook word gevra of die gereformeerde belydenisskrifte nie ook wys in die rigting van die hemel as eindbestemming nie (vgl. NGB artt. 9, 35; HK 19:52; DLR 5.1.2)?

Die vraag wat hier ontstaan is: as die Groot Toekoms uitsluitlik in terme van die (nuwe) hemel beskryf word, hoe moet die Bybelse spreke oor die nuwe aarde dan verstaan word?

Aan die ander kant is daar 'n groot groep dogmatici wat in sterk aardse kategoriee oor die Groot Toekoms dink. By sowel die ouere dogmatici (Dijk, 1949:598; 1953:173-174; Jager, 1962:557-566; Van Ruler, 1972a:157) as die jongere dogmatici (Van Genderen \& Velema, 1992:795; vgl. Heyns, 1978:412$414)$ is dit duidelik merkbaar. Berkouwer (1961:266-267) wys op die gevaar van eensydige hemel-belangstelling en fokus sterk op die nuwe aarde, sonder aandag

1 Vgl. Polman s.j., 320-329; Ott, 1973:435-441; Heyns, 1978:414-416; Bosch, 1991:502-504; Van Genderen \& Velema, 1992:742-743, McClendon, 1994:73-74, 89; vgl. ook Willis, 1987 en Runia, 1997:105-135 
vir die nuwe hemel (1961:270-271). Konig (1980:297) verstaan die nuwe hemel as hemel op aarde; die nuwe mens sal op die nuwe aarde woon (1980:298). Volgens Küng (1983:230) het die nuwe hemel waarvan die Bybel praat, niks te doen met die hemel van vliegtuie en vuurpyle nie. Die naïewe en antromorfe konsep van 'n hemel bo die wolke is vir die moderne mens 'n onmoontlikheid; die "hemel van die geloof" is nie 'n plek nie, maar 'n "wyse van bestaan", oordeel Küng (1993:161-162). Leith (1993:297) beweer dat die hemel as skepping sal verdwyn; om die hemel as bestemming te hê, beteken 'n lewe met God. By Grenz (1994:840-842) verskyn niks spesifieks oor die nuwe hemel nie en val die volle aksent op die nuwe aarde. Ook McGrath (1995:477) verstaan hemel as 'n lewe van "sharing in the community of a loving God" en met die verloste skare. In Moltmann se eskatologie (1996:259 e.v.) word prakties niks oor die nuwe hemel gesê nie; die hemel van Openbaring 21 verdwyn voor die troon van God (Moltmann, 1996:318).

Soms word die aardsheid van die Groot Toekoms in baie konkrete terme beskryf. Hier kan gedink word aan die uitspraak van Thurneysen dat die wêreld van die toekoms geen ander wêreld as die huidige sal wees nie, met hierdie woude, vlaktes, stede, strate, mense - woorde wat Brunner as onbybels afgemaak het (vgl. Berkouwer, 1961:294; Van der Merwe, 1981:160). Ook kan gedink word aan die antwoord van Barth op 'n vraag van Bonhoeffer of die meer van Genève ook dáár sal wees en Barth geantwoord het: "Ja, seker" (Van der Merwe, 1981:159). (By 'n ander geleentheid het Barth (1986:16) die hoop uitgespreek dat hy in die hemel eerstens vir Mozart sal wil opsoek.) Bekend is ook Van Ruler (1972b:114) se uitspraak dat dit in die eskatologie gaan oor die verlossing en verheerliking van die totale geskape werklikheid: "Men kan niet grof genoeg over deze dingen denken". Dit gaan oor die koms van die nuwe aarde (Van Ruler, 1971:225, 228, 231); die hemel is nie die einddoel nie, maar 'n messiaanse intermezzo (Van Ruler, 1973:186). Die uitdagende woorde van Veldkamp (s.j.:314) in sy verklaring van HK 22:58 is nog altyd nadenke werd: "Ik stel mij de nieuwe wereld zo ongeveer voor als deze, maar dan zonder zonde." "Als deze", is dit nie te min gesê nie? "Zonder zonde", is dit nie genoeg gesê nie? Nee, hierdie negatiewe uitspraak is nie genoeg nie, die positiewe moet vooropgaan: God alles in almal; God alles vir alles (1 Kor. 15:28).

Maar ook hier ontstaan 'n vraag: As die Groot Toekoms hoofsaaklik in terme van die nuwe aarde beskryf word, wat moet dan onder nuwe hemel verstaan word?

Dit is daarom begryplik dat 'n derde kategorie denkers in hierdie opsig sinteties dink en sowel aan die kategorie van die nuwe aarde as van die nuwe hemel wil laat reg geskied. Müller (1936:85) sien die hemel as ewige bestemming, maar ook die nuwe aarde, want dit word hemel op aarde (Müller, 1936:96). Honig (1938: 848) is huiwerig om 'n finale konklusie te trek, maar merk op dat daar 'n lewendige verkeer tussen hemel en aarde sal wees - soos trouens ook Kennedy 
(1974:130) van oordeel is: "It seems that the dwelling place of the redeemed will be throughout the entire universe ..." (vgl. Hoeksema, 1973:863). Dijk (s.j.:287; 1949:598) beweer dat die hemel hom met die aarde sal verenig en daarmee lokaal een sal word, 'n gedagte wat ook by Konig terug te vind is. Openbaring 21:1 moet nie verstaan word as (nuwe) hemel én aarde nie, maar - en dis 'n skynbare afleiding - as hemel óp aarde (König, 1980:302). Grudem (1994:1159-1160) aanvaar dat die hemel sowel op 'n toestand as 'n woonplek (van God) dui en konkludeer dan: "It is this place of God's dwelling that will be somehow made new on the time of the final judgement and will be joined to a renewed earth". Maar watter vernuwing sou die woonplek van God benodig? Selfs "somehow"? Is dit dan nie daar vlekvry en sondeloos nie?

Hiermee is 'n aanduiding gegee van die uiteenlopende gedagtes oor die eskatologie, spesifiek oor die nuwe hemel en die nuwe aarde. Is die mens se eindbestemming bloot hemels of slegs aards? Gaan dit oor hemel én aarde of hemel op aarde? 'n Dogmatiese diskoers mag help om oor hierdie vrae groter duidelikheid te verkry en daarom word die volgende oriëntasie aangebied.

\section{Oriëntasie}

\subsection{Sienings uit die vroeë kerkgeskiedenis}

Dit is belangrik om inleidend aandag te gee aan enkele belangrike stemme uit die vroeë kerkgeskiedenis, spesifiek die stemme van Origines en Augustinus.

\section{- Origenes}

Van Origines (185-254) is bekend sy leerstellings van die ewigheid van die skepping, die preëksistensie van die siel en die apokatastasis (vgl. Hand. 3:21) (vgl. Ledegang, 1995:47-48; Küng, 1994:51-53). Op grond van 1 Korintiërs 15:25-28 konkludeer Origines dat uiteindelik - maar na 'n louteringsproses - alle mense, en selfs gevalle engele, weer tot God terugkeer. Origines se eskatologie is dus sterk deur sy universalistiese verlossingsleer gekleur.

Soos genoem, ontwikkel Origines die leer van die apokatastasis (Altaner \& Stuiber, 1980:207-208). Die siele van diegene wat gesondig het, word na die dood gelouter en langsamerhand styg almal - ook die duiwel - omhoog tot 'n vlak van volkome reiniging waar God alles in almal sal wees. Die apokatasiasis beteken egter nie die einde van die wêreld nie, maar net 'n voorlopige afsluiting. Vóór hierdie wêreld was daar ander wêrelde en ná hierdie wêreld sal daar ander wees. Met Plato leer hy die ewige wederkeer van wêrelde. Dit is egter opvallend dat Origines in sy dogmatiese (hoof-) werk, De principiis, waar hy oor die voleinding van die wêreld handel (3.6.1-8), nie eksplisiet die leer oor die apokatastasis ter sprake bring nie (Meyboom, 1921:284-296). 


\section{- Augustinus}

Augustinus volg nie in hierdie opsig die denklyn van Origines nie (vgl. Eger, 1933; Leahy, 1939). Hierdie wêreld gaan verby, nie deur algehele ondergang nie maar deur verandering van die dinge - die gedaante van die wêreld gaan verby (DCD 20.14 - kyk Augustinus, 1983). Die hoedanighede van die bederflike elemente sal volkome ten gronde gaan maar die wese van die dinge ontvang nuwe hoedanighede (2 Pet. 3; DCD 20.156). Daar word gereeld van die nuwe wêreld gepraat (DCD 21.15, 22.10, 22.19).

\subsection{Eskatologie in die Rooms-Katolieke teologie}

In die Rooms-Katolieke teologie speel die eskatologie ook 'n belangrike rol. Van alle dogmatici bied Schmaus (1941) waarskynlik een van die breedvoerigste besprekings van ons vraagstuk. Schmaus (1941:531-532) wys daarop dat die begrip hemel in die Bybel verskillende betekenisnuanses het, waarna hy (Schmaus, 1941:534-559) aandag gee aan die volgende aspekte: die hemel as gemeenskap met Christus, die hemel as onmiddellike aanskouing van God, die hemel as genade en as loon, die hemel as vervulling en beseeling van die mens. Hemel kan ook nog die volgende betekenisnuanses hê: die hemel as die besitname van die van God onderskeie werklikheid; die hemel as die gemeenskap van saliges en die orde in die gemeenskap van die hemel. Die skepping word nie vernietig nie, maar verheerlik en aan die einde staan nie verwoesting nie maar voleinding (1941:588). Die innerlike grond vir die verandering van die wêreld is geleë in sy verbondenheid met die opgestane Christus (Schmaus, 1941:591). Ott (1981:589-590) lewer niks nuuts nie, maar sluit by die tradisionele siening (Augustinus) aan. Hellwig (1991:349-372) vestig die aandag op nuwe benaderings in die Roomse denke. Hans Küng ontmitologiseer die Bybelse gedagte van 'n hemel. Die naïewe en antropomorfe konsep van 'n hemel bo en buite die aarde - die hemel van ruimtereisigers - is vir die modeme mens onaanvaarbaar (Küng, 1983:161, 230; 1993:161). Volgens Küng (1983:161, 1993: 162 ) is die hemel van die geloof nie 'n plek nie maar 'n manier van bestaan, verborge in die onsigbare sfeer van God. Die vraag is egter of hierdie "idealisering" van die hemel hom laat verbind met 'n eskatologie wat - as daad van God - hom in kosmiese dimensies uitdruk (Küng, 1983:237).

In die Rooms-Katolieke kerklike besinning oor die eskatologie het 'n denkverskuiwing plaasgevind. In die vroegste besinning het die ekklesiologiese denkraamwerk gedomineer maar sedert die Middeleeue het die aandag van die "kommunitariese" na die individuele aspek verskuif. Tans word getrag om hierdie twee aspekte saam te dink (Neuner \& Dupuis, 1983:679-680). Roomse dogmas oor die nuwe hemel en aarde is relatief min. Tydens die Tweede Vatikaanse Konsilie (1962-1965) kom dit egter in ten minste twee ensiklieke (pouslike sendbriewe) ter sprake. In Lumen gentium 7.48 word gehandel oor die herstel 
van alle dinge, die vernuwing van die wêreld asook die nuwe hemel en die nuwe aarde binne die konteks van die eskatologiese aard van ons roeping in die kerk (RKK, 1967:97-99).

In Gaudium et spes 3.39 kom die nuwe aarde en nuwe hemel eksplisiet aan die orde (RKK, 1966:431-432). Hierin word gestel dat ons nie weet hoe die heelal omvorm sal word nie, wél sal die hele skepping bevry word van die slawerny en die ydelheid. Die verwagting van 'n nuwe aarde moet die besorgdheid om hierdie aarde uit te bou nie laat afneem nie maar eerder aanwakker. Hoewel aardse vooruitgang sorgvuldig van die groei van die ryk van Christus onderskei moet word, is daar tog ook 'n betrokkenheid ten opsigte van 'n bydrae tot 'n beter ordening van die mensegemeenskap.

In die Rooms-Katolieke kategismusse resoneer dieselfde gedagtes (RKK, 1966:564-568). Die skepping sal volkome heropgerig, misterieus vernuwe en getransformeer word; die wêreld sal na sy oorspronklike staat herstel word (RKK, 1994:271-273).

\subsection{Die nuwe skepping binne die Lutherse tradisie}

In die Lutherse tradisie lê die dinge anders. Die Lutherse ortodoksie het byvoorbeeld die leer van (kosmologiese) annihilasie (en dus radikale diskontinuitteit) aanvaar, veral op grond van Psalm 102:26, 27; Hebreers 12:26-28 (vgl. Berkhof, 1969:737; König, 1980:299; Pannenberg, 1993:571, 633; Van Genderen, 1994:48). Hiervolgens vernietig God die bestaande skepping en 'n totaal ander nuwe skepping word geskep; dit word 'n creatio ex nihilo en nie 'n creatio ex creatione nie - 'n standpunt wat ook by Remonstrante en Sosiniane terug te vind is (Honig, 1938:844). Dit blyk ook duidelik uit die standpunt van Schmid (1983:407; oorspr. 1843) as hy die volgende opmerk: "Nicht also eine Verwandlung der Welt, sondern ein völliges Aufhören ihrer Substanzen ist zu erwarten".

In die latere Lutherse teologie is hierdie standpunt egter laat vaar. In sommige gevalle is daar by Lutherse dogmatici nog 'n terughoudendheid oor die onderwerp. Trillhaas (1962:500-501) laat hom nie daaroor uit nie, Ebeling (1979:508) volstaan met 'n enkele paragraaf oor die nuwe skepping, en Thielicke (1978:552623) wy in sy universele eskatologie geen spesiale aandag aan die nuwe aarde en hemel nie. Hemel verstaan hy (Thielicke, 1978:594) saam met Kierkegaard as "ewige gesprek met Jesus" en as onmiddelike bestaan met God.

Ander Lutherse teoloe is egter meer uitgesproke en wys enersyds daarop dat die nuwe wêreld nie die resultaat is van die aardse kultuurproses nie, maar andersyds dat daar tussen albei tog 'n - hoewel ondeursigtige - verhouding bestaan (Althaus, 1926:250-256; vgl. Vogel, 1952:1059-1060; Pannenberg, 1976:169. 
176). Hoewel die koninkryk van God nie voortvloei uit politieke veranderings nie, het dit tog 'n seènryke invloed op die samelewing (Pannenberg, 1976:175176). Die ryk van God beteken sowel die einde as die voleinding van die geskiedenis (Pannenberg, 1993:632-641) en daarmee tree die ewigheid die tyd binne (1993:641-654).

Daar is konsensus onder Lutherse teoloë dat daar sowel diskontinuiteit as kontinuiteit tussen hierdie skepping en die nuwe skepping sal wees; nuutskepping impliseer dus nie uit-niks-skepping nie (Schlink, 1985:713-719; Nürnberger, 1975:519; Pöhlmann, 1980:337). In 'n histories-kritiese benadering handhaaf Nürnberger (1994:139-149) die essensie van die Bybelse eskatologie, naamlik as 'n hoopvolle heelheid vir die persoon, die samelewing, die wêreld en die heelal.

\subsection{Die nuwe skepping en die gereformeerde teologie}

Hoe oordeel die gereformeerde teologie - sowel in sy meer tradisionele denkpatrone as in die meer kritiese benaderings?

In die tradisionele gereformeerde benadering is daar konsensus van opinie. God sal die teenswoordige gestalte van die wêreld laat vergaan, maar nie die wêreld self nie; die nuwe word uit die oue gemaak (Heppe, 1978:706). Bavinck (1930: 699) wys daarop dat die Skrif nêrens - nie in Noag se tyd nie en nie in die tyd van die voleinding nie - 'n vernietiging van substansie leer nie; alles wat mooi is, word in die nuwe Jerusalem saamgebring, maar vernuwe (Bavinck, 1930:702); die nuwe hemel en aarde word opgebou uit elemente van die wêreld wat tans nog bestaan (Bavinck, 1930:704); die essensie bly behoue terwyl die vorm verander (Bavinck, 1978:566).

Daar is groot ooreenstemming tussen dogmatici ${ }^{2}$ dat daar tussen die ou en die nuwe skepping diskontinuiteit én kontinuiteit bestaan en dat die vernuwing geen repristinasie of restourasie nie maar konsummasie beteken, dus geen herstel van die oorspronklike nie maar voltooiing en voleinding daarvan. Van Genderen (1994:47) wil, saam met Schilder (1954:295) en teenoor Bavinck (1930:702), Dijk (s.j.:288; 1949:600; 1953:185) en Grenz (1994:842), nie weet van 'n kulturele kontinuïteit nie, maar wel van 'n heilshistoriese en pneumatologiese identiteit. Die lyn van die protologie (kreasie) na die eskatologie (glorifikasie) loop oor die Christologie (inkamasie). Bekend is Van Ruler se konkrete en aardse denke. In die eskatologie gaan dit oor die vernuwing van hierdie aarde - en nie oor 'n nova creatio nie (Van Ruler, 1971:223; 1972b:113) - en daar is kon-

2 Vgl Honig, 1938:844-848; Jager, 1962:557-566; Berkhof, 1969:737; Dijk, s.j.:287-288, 1949: 598-600, 1953:171-185; Schilder, 1954:218; Berkouwer, 1961:270-294; Hoeksema, 1973:863; Heyns, 1978:412-416, 1988:410; König, 1980:296-306; Spykman, 1992:558-560; Verkuyl, 1992:467-473, Van Genderen \& Velema, 1992:794-795; Van Genderen, 1994:42-50. 
tinuïteit deur die diskontinuïteit heen (Van Ruler, 1969:168, 225, 227; 1971:239; 1972b:109, 116). "We laten niets vallen, behalwe de zonde" (Van Ruler, 1969:168).

Ook in die kritieser gereformeerde teologie resoneer hierdie gedagtes. ${ }^{3}$

Brunner (1960:475-497) ontvou die eskatologie vanuit die Christusgebeure Christus is sowel die skeppingsgrond as die skeppersdoel. Wat verbygaan, is die gestalte van die wêreld - en wat vernietig word, is die bose magte (wet, sonde, Satan, dood). Die voleinding hef nie die kreatuurlike op nie, maar maak dit volkome. Ons weet egter nie hoe die nuwe wêreld daar sal uitsien nie en daarom moet die realisme van Thurneysen bevraagteken word.

Groot klem word daarop gelê dat die transfigurasie van die wêreld die vrug is van God se versoenende en bevrydende handelinge in Christus (Beker \& Hasselaar, 1990:213), met die opstanding van Jesus as middelpunt (Berkhof, 1968:34). Die toekoms hou enersyds ' $n$ breuk in met die huidige bestaan en andersyds 'n vervulling en bekroning daarvan (Berkhof, 1968:43; 1990:506, 526). "Deze toekomst staat uit ons huidige leven niet rechtstreeks op, maar alleen door het sterven heen" (Berkhof, 1968:63). Die Christen mag nie 'n rewolusionêr wees nie, maar hy moet hierdie wêreld soveel moontlik ombuig na die struktuur van die paradys en die nuwe Jerusalem (Berkhof, 1990:492). Die geboorte van die nuwe wêreld staan nie los van die tegniese en kulturele verworwenhede en van die vooruitgang van die heiligingskragte in hierdie wêreld nie; daarom moet eerder van transformatio as van nova creatio of recreatio gepraat word (Berkhof, 1990:526).

Wat die gereformeerde belydenisskrifte betref, en in besonder die Drie Formuliere van Eenheid, kan sonder oordrywing gesê word dat die eskatologie onderontwikkeld is. Die eskatologie kom wel in die konfessies na vore - vgl. NGB 37 en HK 22 - maar nie in breed uitgewerkte vorm nie. Die vraag is gestel wat van die verlossing van die skepping (Rom. 8) in NGB 37 geword het (Jager, 1962:562), maar tog moet daarop gewys word dat die Belgica bely dat "hierdie ou wêreld" aan vuur en vlam prysgegee word "om dit te suiwer". Uit hierdie weliswaar skrale - verwysing is dit duidelik dat die wêreld (in die voleinding) nuwe kwaliteite ontvang maar dat die substansie dieselfde bly (Polman, s.j.:312).

3 Vgl. Schleiermacher, 1976:717-720; Brunner, 1960:475-497; Berkhof, 1968:25-63, 1990:492506; Van Niftrik, 1972:67 e.v.; Weber, 1972:753-754; Beker \& Hasselaar, 1990:206-213; Kuitert, 1992:226-247; Moltmann, 1996:265, 318. Van Niftrik (1972:69 e.v.) vertolk dit as die realiteit van die hemel, maar dan (soos Barth) slegs m verband met God; die uitsien na die hemel is alleen legitiem as dit oor 'n uitsien na God gaan, want wie God ontvang, ontvang dic hemel. 


\subsection{Eskatologie in die bevrydingsteoiogie}

In sommige nuanses van die bevrydingsteologie word 'n besondere klem gelê op politieke praksis, strukturele transformasie en konkrete denke (Braaten, 1994: 328-352). Eskatologie word nou verbind aan (swart) bevryding (Evans, 1992: 152), terwyl gewys word op die multidimensionele aard van die Bybelse eskatologie: dit raak die individu (opstanding), die gemeenskap en die kosmos (Evans, 1992:153-154). In sy beste uitdrukkings probeer die bevrydingsteologie daarteen waak om menslike utopias met die koninkryk van God te identifiseer (Libânio, 1996:284-285; Evans, 1992:153). Die Bybelse eskatologie rus immers op die hoop op God en sy beloftes.

\section{Dogmatiese oorwegings}

Van die vier eskatologiese opsies, naamlik annihilasie en nova creatio (Lutherse ortodoksie), repristinasie (recreatio), deifikasie 4 (Oosters-Ortodokse teologie) en transformasie het die gereformeerde teologie baie duidelik vir laasgenoemde gekies. Sodoende is gepoog om weg te beweeg van die gevare van gnostisisme, dosetisme, Platonisme, met sy onderwaardering van die aarde, die konkrete, die sigbare en die tasbare. Maar is so 'n anti-idealistiese en anti-spiritualistiese denke Skriftuurlik verantwoord, spesifiek wanneer oor die (nuwe) hemel en die (nuwe) aarde gehandel word?

Die vraag wat onder "nuwe hemel" en "nuwe aarde" verstaan moet word, is dus van groot belang. Moet dit in realistiese terme verstaan word, ook wat die nuwe hemel betref? Of moet die "nuwe hemel" verstaan word as 'n ewige "by God wees"? Maar waar word hierdie "by God wees" konkreet beleef, veral as ons erns wil maak met die belydenis oor die opstanding van die liggaam?

\subsection{Oorwegings by die nuwe hemel}

Van 'n nuwe hemel is daar eksplisiete vermelding in Jesaja 65:17, 66:22 asook in 2 Petrus 3:13 en Openbaring 21:1 - hoewel die saak ook op ander plekke aan die orde gestel word (vgl. Jes. 51:6; Rom. 8:18-30; Heb. 1:11-12; Heb. 12:26-28).

Vir 'n goeie verstaan van die Nuwe-Testamentiese gegewens is die OuTestamentiese eskatologie onmisbaar (vgl. Preuss, 1978; Hartmann, 1960). Die Ou Testament dink baie konkreet oor die skepping van die hemel (šãmájim), sowel in die skeppingsberig van Genesis 1:1 as in die poetiese literatuur (Pss. $121: 2,124: 8,146: 6)$. Verder moet verreken word dat die begrip hemel in die $\mathrm{Ou}$

4 Vgl. Staniloae, 1985:438-445. Moltmann (1996:272) wys daarop dat die Ortodokse teologie onder delfikasie nie verstaan dat mense in gode verander nie. Dit word so verstaan dat mense deelname verkry aan die aard en regte van die Goddelike natuur deur hulle gemeenskap met Christus, die God-mens-wese 
Testament ryk geskakeerde betekenisnuanses besit, soos byvoorbeeld as boaardse ruimte, lugruim, firmament, wolkehemel, sterrehemel en as woonplek van God (Soggen, 1976:965-970; Von Rad, 1985:737-738; en breedvoerig Houtman, 1974:195-219).

Hoewel die hemel as woonplek van God beskryf word (Houtman, 1974:220-253; Wentsel, 1981:204-207), word duidelik uitgespel dat God so groot is dat die hemel Hom eintlik nie kan bevat nie (1 Kon. 8:27). Die hemel word - simbolies woonplek van God genoem, maar eintlik is dit sy regeerplek. God is Skepper van hemel (en aarde) en dit impliseer dat Hy baas daarvan is en dat Hy as almagtige God daaroor heers en daarin handel (Houtman, 1974:66-68, vgl. 107-125). In Genesis 1:1 is die hemel deel van die skepping van God, deel van die geordende kosmos en antipode van die chaos (Houtman, 1974:42-47). Die hemel as skepping kan as bo-aardse werklikheid getipeer word.

Besondere aandag moet aan Jesaja 65:17 en 66:22 gegee word. Volgens Houtman (1974:124) gaan dit hier nie oor die skepping van 'n nuwe kosmos nie, maar gaan dit oor die volledige toewyding van alle wêreldbewoners aan Jahwe, oor die herstel van verwoeste stede, die afwesigheid van trane en vrede in die diereryk. Ook Westermann (1978:527) betrek Jesaja 65:17 op die binne-historiese gebeure en ontdek eers in 66:22 'n geskiedenis-transenderende profesie. Koole (1995: 416-417) aanvaar die beperkende interpretasie (die aarde wys op die land Kanaän), maar daarin is reeds 'n universele strekking (universum) aanwesig (vgl. Young, 1974:514). Ook volgens Vriezen $(1966: 485,486,499)$ gaan die heilsorde wat Jesaja verwag bo die historiese werklikheid uit; dit word 'n universele eskatologie. Ook die hemel word in die soteriologie ingetrek (Von Rad, 1985:738).

Gesien teen die agtergrond van die Ou-Testamentiese boodskap sou Israel nooit aan 'n vernuwing van die hemel as woonplek van God gedink het nie en daarom moet die betekenis van die "nuwe hemel" gesoek word in die rigting van 'n vernuwing van die bo-aardse werklikheid - 'n werklikheid van waaruit die menslike lewe op verskeie maniere bedreig word.

Soos in die Ou Testament het die begrip hemel ook in die Nuwe Testament 'n hele reeks betekenisse (Traub, 1985:736-744; vgl. Barth, 1961:486-558). Die hemel is deel van die kosmos, deel van die skepping van God (Hand. 4:24; Op. 10:6). God se troon is in die hemel (Heb. 8:1), wat 'n aanduiding is - nie soseer van plek nie - maar van God se absolute gesag en volkome heerskappy. Die hemel word ook beskryf as die bestemming van ontslapenes ( 2 Kor. 5:1) en die woonplek van engele (Matt. 28:2). Hemel en aarde word op besondere wyse betrek in die verlossingswerk van Christus (Ef. 1:10; Kol. 1:16). Soos in die Ou Testament word hemel in die Nuwe Testament sowel in teologiese as in realistiese $\sin$ (as bo-aardse werklikheid) verstaan. 
In hierdie konteks moet hemel in 2 Petrus 3:13 en Openbaring 21:1 verstaan word. Morris en Mounce het bepaalde reserwes in hulle verstaan van Openbaring 21. Volgens Mounce (1979:369) moet die nuwe dinge nie verstaan word as primêr "a physical transformation" nie, terwyl Morris (1989:236) meen dat "John is not looking for a new edition of the same thing". Hierteenoor verstaan Greijdanus (1925:416) Openbaring 21:1 baie meer konkreet en kontinu: "Hier is slechts sprake van vormverandering, en van wijziging van verhoudingen; vgl. Matth. 19:28, Hand. 3:21. De gedaante van hemel, en aarde, hun voorkomen, en hunne onderlinge verhouding, waren gansch anders geworden, nieuw, heerlijk". Ook by 2 Petrus 3:13 merk Greijdanus (1929:346) op: "God schept geen gansch nieuwe hemelen nog eene geheel nieuwe aarde, als in den beginne, maar $\mathrm{Hij}$ vernieuwt het bestaande heelal". Bolkestein (1972:301) stem saam dat dit gaan oor 'n herskepping van alle dinge, "een volkomen nieuw worden van de gehele kosmos". So ook Van der Waal (1981:357).

Die konsep kainos moet ons nie op 'n dwaalspoor bring nie. Kainos "is the epitome of the wholly different and miraculous thing which is brought by the time of salvation" (Behm, 1965:449). Dit spreek van wat behoort "bij de heilstijd van Christus" (Van der Waal, 1981:357). Die kontekste waarin die woord gebruik word, is telkens anti-gnosties en anti-dosetisties. Die Bybelse denke is konkreet. Dit gaan oor 'n konkrete nuwe hemel (en 'n nuwe aarde).

Die moderne astronomie gee ons vandag 'n kykie in die onmeetlike heelal en leer ons dat die hemel as bo-aardse werklikheid vol beweging, verandering en ontwikkeling is (vgl. Joubert, 1998). Wat vir die mense-oog na 'n gefikseerde firmament lyk, is alles behalwe vasgelê. Nuwe sterrestelsels word steeds ontdek en nuwe sterre word steeds gebore. Die grense van die heelal - vir sover so iets moontlik is - is vir menslike waarneming en berekening tot nog toe ontoeganglik. Sal God nie eenmaal dit alles in een groot magsgreep tot voltooiing en voleinding bring nie? Ons konklusie is dus dat onder "nuwe hemel" verstaan moet word die vernuwing van die totale bo-aardse werklikheid.

\subsection{Oorwegings by die nuwe aarde}

Soos in die geval van hemel het die begrip aarde in die Ou Testament ook 'n wye reeks betekenisse (Schmid, 1978:227-235). Die aarde is skepping van God, dit vorm saam met die hemel deel van die geskape werklikheid, dit is woonplek van die mens, dit is eiendom van God, dit is aan verganklikheid onderworpe (Jes. 51:6) maar ook op vernuwing ingestel (Jes. 65:17; 66:22). Oor die betekenis van aarde in Jesaja 65:17 en 66:22 het ons reeds gehandel. Die handelinge van God met sy volk en met sy kosmos is konkreet en tasbaar en op voleinding afgestem, en kosmologie en Teologie (Godsleer) is in die Ou Testament steeds ten nouste met mekaar verbonde. 
Dieselfde tendens sit hom in die Nuwe Testament voort (Sasse, 1985:116-117). Ook daar is die aarde woonplek van die mens, deel van die geskape werklikheid, skepping en daarom eiendom van God (1 Kor. 10:26). Die aarde is egter ook teater van sonde en geskiedenis, en so van verganklikheid (1 Kor. 7:31), maar ook voorwerp van God se vernuwende krag (2 Pet. 3:13; Op. 21:1).

Die "skema" van hierdie wêreld gaan verby (1 Kor. 7:31; vgl. 1 Joh. 2:17). Die aarde sal eenmaal "vergaan" (Heb. 1:11;2 Pet. 3:13), maar beteken dit dat die aarde heeltemal tot niet sal gaan en 'n nuwe ander aarde geskape sal word? Reeds die duidelike parallellie in 2 Petrus 3 tussen die "vergaan" van die aarde in die dae van Noag (vers 6) en die "vergaan" van die aarde op die jongste dag (vers 10), moet ons daarvan weerhou om in terme van annihilasie te dink. Die gegewens in Romeine 8:21 en Openbaring 21:2 wys daarvoor te sterk in die rigting van kontinuïteit tussen hierdie aarde en die nuwe (dus hernude) aarde. Ongetwyfeld is daar ook diskontinuiteit, daar is 'n oordeel en daarom 'n proses van suiwering. Maar dit is hierdie aarde wat gesuiwer en gelouter, gereinig en geheilig word, as woonplek van konkrete mense, mense met geestelike liggame (1 Kor. 15:44).

Die nuwe aarde sal die ewige tuiste van die nuwe verloste mensheid wees. En die nuwe hemel dan? Dit sou myns insiens 'n dosetistiese vervlugtiging wees om "hemel" slegs te verstaan as "by God wees" (Hanson \& Hanson, 1981:201). Leef die verloste mens dan nie nou reeds coram Deo nie? Natuurlik sal die lewe met God op die nuwe aarde voller, heerliker en heiliger wees, opgevoer tot ongekende en onvoorstelbare hoogtes (1 Kor. 2:9), maar dit sal 'n konkrete lewe iewers wees. Plek verdwyn nie in die ewigheid nie, maar neem nuwe dimensies aan. Vandaar dat daar veel ten gunste van die reeds eerder genoemde standpunte van Honig (1938:848) en Kennedy (1974:130) gesê kan word, naamlik dat daar 'n lewendige verkeer tussen hemel en aarde sal plaasvind en dat die verlostes die "entire universe" as woonplek sal hê.

\subsection{Dle geheim}

Hierdie deel mag nie afgesluit word sonder om kortliks te wys op die geheim wat die toekoms ontsluit nie. Dit moet gesoek word in die verbondstrou van die lewende God wat nie die werk van sy hande laat vaar nie (Ps. 138:8). God gee nie sy skepping oor aan die magte van sonde, dood en demone nie, maar gryp in Christus en sy Gees bevrydend en vernuwend in op die gebroke werklikheid. "Toen de zonde gekomen was, heeft de Zoon gedacht: Dan kom Ik ook!" (Noordmans, 1980:237).

Tereg sê Van Genderen (1994:24): "De christologie is het fundament van het eschatologie en de christologie leidt tot een andere eschatologie dan de joodse". 
Die transfigurasie van die wêreld is die vrug van God se versoenende en bevrydende handelinge in Christus (Beker \& Hasselaar, 1990:213). "De poort naar de eschatologiese werklijkheid is Christus" (Van de Beek, 1996:225; vgl. Brunner, 1960:475-497). Saam met die versoeningswerk van Christus moet ook die vernuwingswerk van die Heilige Gees genoem word sodat gesê kan word dat die Christologie en Pneumatologie bepalend is vir die eskatologie.

Die koms en opstanding van Jesus Christus staan sentraal in God se heilsplan en in die wêreldgeskiedenis. Nie net die kruis nie, maar ook die opstanding (Pannenberg, 1976:105; 1991:343-363; Van Ruler, s.j.29, 33, 168; 1972a:103-105, 151152), nie net die opstanding nie maar ook die kruis. Die kruis bring versoening en die opstanding bring verlossing (Noordmans, 1980:302). Die kruis is die simbool van oorwinning oor die sonde, en die opstanding van oorwinning oor die dood (Kol. 2:13-15). God het in Christus die bose magte oorwin en 'n openbare skouspel van hulle gemaak (1 Kor. 15:24; Ef. 4:8; Kol. 2:15; Heb. 2:14-15). Vanuit die versoeningswerk van Christus kan dus gekonkludeer word dat iemand wat aan Christus behoort, 'n nova creatura (kaine ktisis) is (2 Kor. 5:17). Wie deur die doop met Christus verenig is, voer nou reeds 'n "nuwe lewe" (Rom. 6:4), die ewigheid begin in die tyd (Joh. 3:36). God is reeds en steeds besig om álles nuut te maak (Op. 21:5) - die werkwoordsvorm is in die onvoltooid teenwoordige tyd. Hierdie álles sluit in: nuwe mense, nuwe Jerusalem, nuwe aarde en nuwe hemel.

Alles is deur die Seun en vir die Seun geskep (Kol. 1:16). Die bedoeling van God is om alles wat in die hemel en op die aarde is onder een hoof, Christus, te verenig (Ef. 1:10).

Die werk van die Heilige Gees mag in hierdie opsig ook nie vergeet word nie (vgl. Pannenberg, 1993:588-598). Die lewewekkende en vernuwende werk van die Gees moet nie net op die mens en die kerk betrek word nie, maar ook op die skepping (vgl. Pss. 33:6; 104:30) en die herskepping. Dit is deur sy Gees dat God die sugtende skepping bevry van sy verslawing aan die verganklikheid (Rom. 8:21-23). Dit is die Gees wat mense begiftig en lei op die weg van bekering en vernuwing in die rigting van die beloofde toekoms.

Met die koms van Christus en die Gees het die koninkryk van God gekom (Matt. 12:28), is dit soos suurdeeg werksaam in die wêreld (Matt. 13:33) en stuur dit onherroeplik af op voltooiing en voleinding. Die mens bevind hom in die interimperiode tussen koms en wederkoms, tussen begin en einde, tussen oorsprong en voleinding. 


\section{Etiese oorwegings}

\section{- Eskatologie en etiek}

Oor die tema eskatologie en etiek 5 is daar al heelwat besin. Die belangrikheid van die eskatologie vir die etiek, en die invloed daarop, is evident: noudat die koninkryk van God gekom het, en in alles éérste gesoek moet word (Matt. 6:33), kom alle ander dinge, ook alle ander menslike aktiwiteite, in 'n nuwe lig en in 'n ander konteks te staan (Rom. 13:12;14:17). In die lig van die onverwagte koms van Christus word Christene aangespoor tot 'n lewenshouding van waaksaamheid (Matt. 24:42-51; 25:13) en gebed (Mark. 13:33; Luk. 21:36), 'n lewe van wakker en nugter wees (1 Tess. 5:6).

Die geskiedenis is ingestel op die voleinding. Die voleinding trek die geskiedenis aan, die geskiedenis dring na die voleinding (Van Ruler, 1969:19; 1971:225-228; 1972b:105-106; Velema, 1985:168). Die toekomsverwagting moet die geskiedenis - en die lewe - stimuleer en dirigeer. Die toekoms bepaal die hede - méér as die hede die toekoms.

Die opmerking van Van Genderen (1994:63) is korrek: "De eschatologie heeft consequenties voor de ethiek". Overduin (s.j. :6) weer stel dit só: "Een ethiek zonder eschatologie is de vrome dood; een eschatologie zonder ethiek is het najagen van een ziekelijk denkbeeld". By die verwagting van die dag van God hoort die beywering daarvoor (2 Pet. 3:13). Die Christelike geloof is nie 'n wêreldvreemde geloof wat die aandag van die aarde wegtrek nie. Die verwagting van die toekoms werk nie relativerend nie, maar stimulerend ten aansien van ons aandag vir die wêreld (Berkouwer, 1974:281).

\section{- Parousia en algehele lewensheiliging}

Die verhaas van die parousia in 2 Petrus 3:13 staan in verband met algehele lewensheiliging (Rabali, 1992:152-154, 180-181), met 'n besondere aksent op dade van geregtigheid (Rabali, 1992:159, 177-178). "The Christian community 'hastens' the day of the Lord when it is diligently concerned for both quantity and quality with regard to all the tasks assigned for it" (Rabali, 1992:154). Die verhaasmotief raak ook die roeping van die kerk in die wêreld: "Hastening the day of the Lord entails, among other things, that effort (diligence) is made to establish peace and righteousness in anticipation of the parousia; it implies that the Christian community exercises a critical prophetic and diaconal ministry with regard to the world" (Rabali, 1992:245).

5 Vgl. onder andere Rothuizen, 1962:215-258; Heering, 1969:95-111; Van Wyk, 1986 224-239; Van Wyk, 1991:403-425; Lohsc, 1991:39-47, Van de Beek, 1996:228-233, 359-405 Meer uitgebreid De Graaf, 1955; Nicol, 1984. 
Naas 'n houding van waaksaamheid in die tussentyd roep Christus op tot 'n lewe van werksaamheid (Matt. 25:14-46; vgl. 1 Kor. 3:13-15). Dit roep onmiddellik die vraag na vore in verband met die betekenis van ons aardse werk - 'n vraag wat ons hier nader ondersoek. Vervul ons werk enige funksie in verband met die koms van die Groot Toekoms? Lewer dit boustene vir die koms van die koninkryk - soos Van Ruler (1972b:116) oordeel?

Bosch (1991:506) praat in hierdie verband van "the sin of temerity" waar die mens in vermetelheid sy eie werk oorskat, en "the sin of timidy" waar die mens in beskroomdheid vir minder hoop as wat belowe is. Inderdaad is hier tweërlei lewenshouding moontlik: of die mens dink dat hy alles kan doen (fanatisme), of hy dink dat hy niks hoef te doen nie (fatalisme) (Verkuyl, 1992:470). Sölle (1993:210) weer is van mening dat die voortbestaan van die skepping van die krag van die liefde onder mense afhang.

\section{- Kultuurmandaat}

In hierdie verband moet enkele opmerkings oor die kultuurmandaat gemaak word, veral soos dit in verband gebring word met die indra van kultuurskatte in die Nuwe Jerusalem (Op. 21:24, 26). Terwyl sommige teoloë hieroor negatief oordeel, is ander meer positief (Bavinck, 1930:702; Dijk, s.j.:288; 1949:600; 1953:185; Grenz, 1994:842). Douma (1989:50-55) is krities oor die standpunte van Kuyper en Schilder. Self wys hy die gedagte af dat die mens 'n kultuurprogram sou hê wat voor die wederkoms afgewerk moet word (Douma, 1989:53, $55 ; 1990: 197)$. Ook verwerp hy die mening dat menslike kultuurprestasies as boustene vir die koninkryk van God kan dien (Douma, 1989:54), hoewel hy die vraag oophou of die kulturele effekte van (selfs) nie-Christene nie ook die Nuwe Jerusalem sal haal nie (Douma, 1990:199-200). Hierteenoor het Velema ${ }^{6}$ hom telkens krities oor die begrip kultuurmandaat uitgelaat en wel ten gunste van die tema van roeping (Velema, 1974:45-58; 1996:32-38; vgl. ook Wolterstorff, 1984: 140-143; Van Genderen, 1994:43; Van Rooy, 1997:1-15). Volgens Velema word die kultuurmandaat te veel buite Christus om gehanteer sodat dit die soteriologiese kader van die koninkryk van God ignoreer. Lewe in die tussentyd word enersyds gestempel deur evangelieverkondiging en andersyds deur vreemdelingskap. Ons kultuurarbeid loop nie uit op die voltooiing van die geskiedenis nie. Teen die gedagte van bou aan die koninkryk bestaan daar veel besware (vgl. Van de Beek, 1996:205-211).

Uit die Skrifgetuienis is dit duidelik dat die mens se arbeid in die tussentyd sinvol is en deur God - op 'n vir die mens ondeursigbare wyse - gebruik word in die

6 In sy artikel gaan Velema (1997:62-74) verder hierop in. Hy wys daarop dat ons vanuit die skepping in die etick moet praat van opdrag, vanuit die genade van geskenk en vanuit die toekoms van belofre (1997:73). 
koms van die nuwe aarde en hemel. Die gehalte van elkeen se werk sal deur vuur getoets word, maar daar is werk wat "bly staan" (1 Kor. 3:14); daar is werk wat ook na iemand se dood nog sy betekenis behou (Op. 14:13), en ja, die skatte en rykdom van die nasies sal die Nuwe Jerusalem haal (Op. 21:26). Dit alles maak nog nie die koms van die nuwe aarde en hemel van menslike aktiwiteite afhanklik nie, want dit is Hy wat op die troon sit, God die Almagtige, wat alles nuut maak (Op. 21:5). Die Nuwe Jerusalem daal van bo af op die aarde neer en groei nie van onder omhoog nie (Op. 21:2). Die nuwe skepping is 'n geskenk van God, uit genade. Selfs die volke kry daar 'n toegewese plek (Op. 21:3), maar dan bevry van konflik en vyandskap (Verkuyl, 1992:468; Moltmann, 1996:315 e.v.). So kry hierdie teks uit Openbaring 21:3 - maar dan losgemaak van sy misbruik deur 'n apartheidsteologie (vgl. Müller, 1936:84) - 'n nuwe betekenis.

Wie die nuwe aarde en die nuwe hemel verwag, moet hom nou reeds daarvoor beywer (2 Pet. 3:13). Omdat ons 'n nuwe skepping verwag, daarom moet ons ons beywer om vlekkeloos en onberispelik voor en in vrede met God te lewe ( 2 Pet. $3: 14)$, daarom moet ons ons beywer vir die geregtigheid, vrede en vreugde, wat die Heilige Gees gee (Rom. 14:17), en vir die evangelieverkondiging wêreldwyd (Matt. 24:14). Nadat Paulus die eskatologiese verwagting van die opstanding breed uiteengesit het, sluit hy af met: "Daarom, liewe broers, wees standvastig, onwankelbaar, altyd oorvloedig in die werk van die Here, omdat julle weet dat julle inspanning in diens van die Here nie tevergeefs is nie" (1 Kor, 15:58). "Wij kunnen en zullen de voleinding niet tot stand brengen en realiseren, maar wij worden wel geroepen te handelen en te wandelen in de richting van het geen komende is" (Verkuyl, 1992:470). Anders gesê: "Christians must be clear that they do not bring or build the kingdom, but neither are they to wait passively for its full realization. Christians are kingdom workers, not kingdom builders" (Snyder, 1991:153).

As werker bly die mens 'n vreemdeling op aarde; as vreemdeling bly hy 'n werker. Die menslike arbeider tydens die interim is nie vergelykbaar met 'n sandkasteelbouer, wie se werk uiteindelik totaal verdwyn as die water daaroor spoel nie, ook nie met dié van 'n paneelklopper wat opknap-werk doen nie, maar met dié van 'n tegnoloog wat steenkool onder hoë druk en hitte plaas en so diamente produseer. God gebruik ons werk en kultuurprodukte, maar gesuiwer en gereinig.

\section{Samevatting: Van utopie tot eutopie}

"Ons leef in die verwagting van 'n nuwe hemel en 'n nuwe aarde wat God belowe het en waar die wil van God sal heers" (2 Pet. 3:13). Daarmee is die Christelike lewe gestempel as 'n lewe van verwagting en hoop op die beloftes van God (Rom. 8:24-25) - 'n aspek waarvoor Moltmann (1969) so indringend ons aandag gevra het (vgl. ook Barth, 1959:1066-1083; Steen, 1997:143-173). 
Die mens is nie op weg na 'n utopie nie, 'n geen-plek, maar na 'n eutopie, 'n goeie plek - 'n nuwe skepping.

Die hoop bevry ons van moedeloosheid, vrywaar ons ook teen oormoedigheid en gee ons moed vir die toekoms. Die hoop gee ons vertroue, nie in ons eie kragdadigheid nie, want dit is baie broos, maar in die krag van God by wie niks onmoontlik is nie (Jer. 32:17, 26; Luk. 1:37). Die hoop bewaar ons sowel van neerdrukkende pessimisme as van oppervlakkige optimisme en leer ons wat ware spesimisme is - hoop wat op Gód gerig is (vgl. Nicol, 1984:182-190).

Die Christelike hoop bring verwagting en protes (Migliore, 1991:247-251). Die hoop laat ons deelneem aan die stryd vir vernuwing van alle dinge. Dit laat ons as Protestante - protesteer teen individuele en sosiale onreg, teen dieremishandeling en teen ekologiese versteuring. Dus: "Geen vaag futurisme, geen kalmerende utopie, maar eschatologische dáádwerkelijkheid zonder quiëtisme" (Berkouwer, 1974:286). Andersyds bewaar die Christelike hoop ons van aktivisme, want ons hoop nie op onsself of op menslike prestasies nie, maar op God wat voleindig wat $\mathrm{Hy}$ begin het.

God is die God van hoop wat 'n nuwe toekoms skep (Jer. 29:11).

\section{Bibliografie}

ALTANER, B. \& STUIBER, A. 1980. Patrologie: Leben, Schriften und Lehre der Kirchenvăter. Freiburg : Herder

ALTHAUS, D P. 1926 Die letzten Dinge: Entwurf einer Christlichen Eschatologie. Gütersloh Bertelsmann

AUGUSTINUS, A. 1983. De stad van God. Baam : Ambo. (Vert. G. Wijdeveld.) (Aangehaal as DCD.)

BARTH, K. 1959. Die Kirchliche Dogmatik 4.3(2). Zurich : Evangelischer Verlag.

BARTH, K. 1961. Die Kirchliche Dogmatik 3.3. Zürich : EVZ-Verlag.

BARTH, K 1986. Wolfgang Amadeus Mozart Grand Rapids : Eerdmans.

BAVINCK, H. 1930. Gereformeerde Dogmatiek 4. Kampen : Kok.

BAVINCK, H 1978. Our reasonable faith: A survey of Christian doctrine. Grand Rapids Baker.

BEHM, J. 1965. Kainós. (In Kittel, G, ed. Theological Dictionary of the New Testament. Grand Rapids : Eerdmans. p. 447-450.)

BEKER, EJ \& HASSELAAR, J M. 1990 Wegen en kruispunten in de dogmatiek 5: Kerk en toekomst Kampen : Kok.

BERKHOF, H. 1968. Gegronde verwachting: Schets van een Christelijke toekomstleer. Nijkerk : Callenbach

BERKHOF, L. 1969. Systematic theology. Londen : The Banner of Truth Trust

BERKHOF, H. 1990. Christelijk geloof: Een inleiding tot de geloofsleer. Nijkerk : Callenbach.

BERKOUWER, G C 1961. De wederkomst van Christus I. Kampen : Kok.

BERKOUWER, G.C. 1974. Een halve eeuw theologie: motieven en stromingen van 1920 tot heden Kampen : Kok

BOICE, J.M. 1986. Foundations of the Christian faith: A comprehensive and readable theology. Leicester : InterVarsity Press. 
BOLKESTEIN, M.H. 1972. De brieven van Petrus en Judas. Nijkerk : Callenbach.

BOSCH, D.J. 1991. Transforming mission. Paradigm shifts in theology of mission New York : Orbis.

BRAATEN, C.E. 1994. The kingdom of God and life everlasting. (In Hodgson, P.C. \& King, R.H., ed. Christian theology: An introduction to its tradition and tasks. Minneapolis Fortress. p. 328-352.)

BRUNNER, E. 1960. Die christliche Lehre von der Kirche, vom Glauben und von der Vollendung. Dogmatik Band III. Zürich : Zwingli-Verlag.

DCD

Kyk Augustinus. 1983

DE GRAAF, J. 1955. Ethos en eschaton Assen : Pangorfum.

DIE LEWENDE BYBEL. 1982. Roodepoor : CU.

DIJK, K. s.j. Korte Dogmatiek. Kampen : Kok

DUK, K. 1949. De leer der laatste dingen. (In Berkouwer, G.C. \& Toornvliet, G., red. Het dogma oor kerk. Groningen : Jan Haan p. 560-607.)

DIJK, K. 1953. Over de laaste dingen III: De toekomst van Christus. Kampen : Kok.

DOUMA, J. 1989. Milieu en manipulatie. Kampen : Van den Berg

DOUMA, J. 1990. Christus en cultuur. (In Douma, J., et al., red. Schilder: Aspecten van zijn werk. Barneveld : De Vuurbaak p. 169-201.)

EBELING, G. 1979. Dogmatik des christlichen Glaubens III: Der Glaube an Gott den Vollender der Welt. Tübingen : JCB Mohr (Paul Siebeck)

EGER, H 1933. Die Eschatologie Augustins. Bamberg : Greifswald.

EVANS, J.H. 1992. We have been believers: An African-American Systematic Theology Minneapolis : Fortress.

GREIJDANUS, S. 1925. De Openbaring des Heeren aan Johannes (Kommentaar op het Nieuwe Testament). Amsterdam : Bottenburg.

GREIJDANUS, S. 1929. De Brieven van de apostelen Petrus en Johannes, en de brief van Judas. (Kommentaar op het Nieuwe Testament.) Amsterdam : Bottenburg.

GRENZ, S.J. 1994 Theology for the community of God. Nashville : Broadman \& Holman

GRUDEM, W. 1994. Systematic theology: An introduction to Biblical doctrine. Grand Rapids : Zondervan.

HANSON, A. \& HANSON, R. 1981. Reasonable belief: A survey of the Christian faith. Oxford: Oxford University Press.

HARTMANN, B. 1960. Himmel und Erde im AT Schweizerische Theologische Umschau, 30:221-224.

HEERING, H.J. 1969 Ethiek der voorlopigheid. Nijkerk : Callenbach.

HELLWIG, M.K. 1991. Eschatology. (In Fiorenza, F.S. \& Galvin, JP., ed Systematic theology: Roman Catholic Perspectives II. Minneapolis : Fortress Press. p. 349-372.)

HEPPE, H. 1978. Reformed dogmatics - set out and illustrated from the sources. Grand Rapids : Baker. (Oorspr. 1816.)

HEYNS, J A. 1978. Dogmatiek. Pretoria : NG Kerkboekhandel

HEYNS, J.A 1988. Inleiding tot die dogmatiek - aan die hand van die Nederlandse Geloofsbelydenis. Pretoria : NG Kerkboekhandel.

HOEKSEMA, H. 1973. Reformed Dogmatics. Grand Rapids : Reformed Free Publishing Association.

HONIG, A. 1938 Handboek van de gereformeerde dogmatiek. Kampen : Kok

HOUTMAN, C. 1974. De hemel in het Oude Testament: Een onderzoek naar de voorstellingen van het oude Israel omtrent de kosmos. Franeker : Wever

JAGER, O 1962. Het eeuwige leven: met name in verband met de verhouding van tijd en ceuwigheid. Kampen : Kok. 
J.H. van Wyk

JOUBERT, G. 1998. Die groot gedagte: abstrakte weefsel van die kosmos. Kaapstad Tafelberg

KENNEDY, D.J. 1974. Truths that transform: Christian doctrines for your life today. Old Tappan : Fleming H Revell Company

KONIG, A 1980 Gelowig nagedink (2) oor die einde: Jesus die laaste. Pretoria : NG Kerkboekhandel

KOOLE, J.L. 1995. Jesaja III. Kampen : Kok.

KUITERT, H.M. 1992. Het algemeen betwijfeld christelijk geloof Een herziening. Baam Ten Have.

KÜNG, H 1983 Eeuwig leven? Hilversum : Gooi \& Sticht.

KÜNG, H. 1993. Credo: The Apostle's Creed explained for today Londen : SCM Press

KÜNG, H. 1994. Great Christian thinkers. Londen : SCM Press.

LEAHY, D.J. 1939. St. Augustine on eternal life. London : s.n.

LEDEGANG, F. 1995. Origines: Een experimental theoloog uit de derde eeuw. Kampen Kok.

LEITH, J.H. 1993. Basic Christian doctrine. Louisville : John Knox Press

LIBÂNIO, J.B. 1996. Hope, utopia, resurrection. (In Sobrino, J. \& Ellacuria, I, ed. Systematic Theology: Perspectives from Liberation Theology. Maryknoll : Orbis. p. 279-290.)

LOHSE, E. 1991. Theological ethics of the New Testament. Minneapolis : Fortress

McGRATH, E. 1995 Christian theology: An introduction. Cambridge : Blackwell.

McCLENDON, J.Wm. 1994 Systematic Theology II: Doctrine. Nashville : Abingdon Press.

MEYBOOM, H.U. 1921. Oud-Christelijke geschritten 31: Origines 1: Over de (hoofd) beginselen (der geloofsleer). Leiden : Sijthoff.

MIGLIORE, D.L. 1991. Faith seeking understanding: An introduction to Christian theology. Grand Rapids : Eerdmans.

MOLTMANN, J 1969. Theologie van de hoop. Utrecht : Ambo

MOLTMANN, J 1996. The coming of God: Christian eschatology. Londen : SCM Press

MORRIS, L. 1989. Revelation. (Tyndale New Testament Commentaries). Grand Rapids Eerdmans

MOUNCE, R.H 1979. The book of Revelation. (The New International commentary on the New Testament) Grand Rapids : Eerdmans

MULLER, J.J. 1936. Toekomsverwagtinge. Stellenbosch : CSV.

NEUNER, J. \& DUPUIS, J., ed. 1983. The Christian faith - in the doctrinal documents of the Catholic Church. Londen : Collins

NICOL, W. 1984. Die betekenis van die eskatologie vir die sosiale etiek. Stellenbosch : US

NOORDMANS, O. 1980. Verzamelde werken 8: Meditaties. Kampen : Kok.

NURNBERGER, K. 1975. Sistematiese teologie. Genadendal : Morawiese Boekdepot.

NÜRNBERGER, K. 1994. Towards a new heaven and a new earth. (In De Gruchy, J. \& VillaVicencio, C., ed. Doing theology in context: South African Perspectives I. Kaapstad David Philip p. 139-149.)

OTT, H. 1973. Die Antwort des Glaubens: Systematische Theologie in 50 Artikeln. Stuttgart : Kreuz Verlag

OTT, L. 1981. Grundriss der katolischen Dogmatik. Freiburg : Herder.

OVERDUIN, J. s.j Het onaantasbare: Over de christelijke hoop. Kampen : Kok

PANNENBERG, W 1976. De geloofsbelijdenis. Een uitleg van de apostoliese geloofsbelijdenis voor mensen van nu. Baarn : Ten Have.

PANNENBERG, W. 1993. Systematische Theologie III Gottingen: Vandenhoeck \& Ruprecht

PÖHLMANN, H.G. 1980 Abriss der Dogmatik Gütersloh : Gutersloher Verlagshaus Gerd Mohn. 
POLMAN, ADR s.j. Onze Nederlandsche Geloofsbelijdenis - verklaard uit het verleden, geconfronteerd met het heden IV. Franeker : Wever

PREUSS, H.D. (Hrsg). 1978. Eschatologie im Alten Testament. Darmstadt : Wissenschaftlische Buchgesellschaft.

RABALI, T.C. 1992. The motif of hastening the Lord's coming: 2 Peter 3:1-13 and its alleged parallels and background. Pretoria : Unisa.

RKK. 1966 De nieuwe katechismus: Geloofsverkondiging voor volwassenen. Antwerpen Paul Brand

RKK. 1994 The Catechism of the Catholic Church. Gwem : Mambo

ROTHUIZEN, G.Th. 1962. Primus usus legis: Studie over het burgerlijk gebruik van de wet. Kampen : Kok.

RUNIA, K. 1997. Eschatology in the second half of the twentieth century. Calvin Theological Journal, 32(1): I05-135, April.

SASSE, H. 1985. Earth. (In Kittel, G. \& Friedrich, G. Theological Dictionary of the New Testament. Abridged in one volume by G.W. Bromiley. Grand Rapids : Eerdmans p. 116-117.)

SCHLDER, K. 1954. Wat is de hemel? Kampen : Kok

SCHLEIERMACHER, F. 1976. The Christian faith. Edinburgh : Clark.

SCHLINK, E. 1985. Okumenische Dogmatik. Grundzüge. Götingen : Vandenhoeck \& Ruprecht

SCHMAUS, M. 1941. Katolische Dogmatik I13: Die Lehre von den Sakramenten und von den letzten Dingen. Munchen : Max Hueber.

SCHMID, H.H. 1978. Erde, land (In Jenni, E \& Westermann, C Hrsg. Theologisches Handwörterbuch zum Alten Testament I München : Kaiser. p. 227-235.)

SCHMID, H. 1983. Die Dogmatik der evangelisch-lutherischen Kirche dargestelt und aus der Quellen belegt. Gütersloh : Gütersloher Verlagshaus Gerd Mohn.

SNYDER, H.A. 1991. Models of the kingdom. Nashville : Abingdon Press.

SOGGEN, J.A. 1976. Himmel (In Jenni, E. \& Westermann, C Hrsg. Theologisches Handwörterbuch zum Alten Testament II München : Kaiser. p. 965-970.)

SOLLE, D 1993. Denken over God: Inleiding in de theologie Baarn: Ten Have

SPYKMAN, G.J. I992. Reformational theology: A new paradigm for doing dogmatics Grand Rapids : Eerdmans.

STANILOAE, D. 1985. Orthodoxe Dogmatik. Zurich : Benziger Verlag

STEEN, M. 1997. De veerkracht van de christelijke hoop. Collationes (Vlaams Tijdschrift voor Theologie en Pastoraal), 27(2):143-173, Junie.

THIELICKE, H. 1978. Der Evangelische Glaube III: Theologie des Geistes Tübingen : JCB Mohr (Paul Siebeck).

TRAUB, H 1985. Ouranos. (In Kittel, G. \& Friedrich, G. Theological Dictionary of the New Testament. Abridged in one volume by G.W. Bromiley. Grand Rapids : Eerdmans. p. 736-744.)

TRILLHAAS, W. 1962. Dogmatik. Berlyn : Alfred Topelmann.

VAN DE BEEK, A. 1996. Schepping: De wereld als voorspel voor de eeuwigheid Nijkerk

Callenbach

VAN DER MERWE, H. 1981. Verwagting en voleinding Pretoria : NG Kerkboekhandel

VAN DER WAAL, C. 1981. Openbaring van Jezus Christus II. Verklaring Oudkarspel : De Nijverheid

VAN GENDEREN, J. 1994. De nieuwe hemel en de nieuwe aarde Kampen : Kok.

VAN GENDEREN, J. \& VELEMA, W.H. 1992. Beknopte Gereformeerde Dogmatiek Kampen : Kok

VAN NIFTRIK, G.C. 1972. De hemel: over de ruimtelijkheid van God Nijkerk : Callenbach 
VAN ROOY, H.F. 1997 Die implikasies van die Bybelse kultuurmandaat (Gen. 1:28 en 2:15) van bewoon, bewerk, beheers en bewaak vir ontwikkeling - 'n prinsipiele perspektief. Potchefstroom : IRS Studiestuk no. 351, p. 1-15, Maart.

VAN RULER, A.A. s.j. De dood wordt overwonnen: 1 Korinthe 15 in morgenwijdingen. Nijkerk : Callenbach.

VAN RULER, A A 1969. Theologisch Werk Deel I. Nijkerk : Callenbach.

VAN RULER, A A. 1971. Theologisch Werk Deel II. Nijkerk : Callenbach.

VAN RULER, A A. 1972a. Ik geloof: De twaalf artikelen van het geloof in morgenwijdingen. Nijkerk : Callenbach.

VAN RULER, A.A. 1972b. Theologisch Werk Deel IV. Nijkerk : Callenbach

VAN RULER, A.A. 1973. Theologisch Werk Deel VI. Nijkerk : Callenbach.

VAN WYK, JH 1984 Calvyn oor die Christelike lewe. Pretoria : NG Kerkboekhandel

VAN WYK, J.H 1986. Gesindheid en gestalte. Pretoria : NG Kerkboekhandel.

VAN WYK, J.H. 1991. Moraliteit en verantwoordelikheid: Opstelle oor politieke etiek. Potchefstroom : PUCHO.

VELDKAMP, H. s.j. Zondagskinderen: Kanttekeningen bij de Heidelbergse Catechismus I. Franeker: Wever

VELEMA, W.H. 1974. Ethiek en pelgrimage: Over de Bijbeise vreemdelingschap. Amsterdam : Ton Bolland.

VELEMA, W.H. 1985. Geroepen tot heilig leven Kampen : Kok.

VELEMA, W H. 1996. Door het Woord bewogen. Leiden : Groen \& Zoon.

VELEMA, W.H. 1997. Ethiek tussen Eden en eschaton. (In Schaeffer, J.H.F., Smit, J.H \& Tromp, Th., red. Nuchtere noodzaak: Ethiek tussen navolging en compromis. Opstellen aangeboden aan prof. dr. J. Douma. Kampen : Kok p. 62-74.)

VERKUYL, J. 1992. De kern van het Christelijk geloof. Kampen : Kok

VOGEL, H 1952. Gott in Christo: Ein Erkenntnisgang durch die Grundprobleme der Dogmatik. Berlyn : Lettner.

VON RAD, G. 1985. Ouranós. (In Kittel, G. \& Friedrich, G. Theological Dictionary of the New Testament. Abridged in one volume by G.W. Bromiley. Grand Rapids : Eerdmans p. 737-738.)

VRIEZEN, Th C 1966. Hoofdlijnen der theologie van het Oude Testament. Wageningen Veenman \& Zonen.

WEBER, O. 1972. Grundlagen der Dogmatik II Neukirchen-Vluyn : Neukirchener Verlag.

WENTSEL, B. 1981. Dogmatiek I: Het Woord, de Zoon en de dienst. Kampen : Kok.

WESTERMANN, C. 1978 Hädâs (In Jenni, E. \& Westermann, C. Hrsg. Theologisches Handworterbuch zum Alten Testament II München : Kaiser p. 524-530.)

WILLIS, W., ed. 1987. The kingdom of God in 20th-century interpretation. Peabody Hendrickson.

YOUNG, E J 1974. The book of Isaiah III. Grand Rapids : Eerdmans. 
